\title{
Simple Synthesis of Some Novel Polyfunctionally Derivatives of 2H-Coumarin-2-One.
}

\author{
H.A. Latif, M.A. Barsy, E.A. Elrady \\ Department of Chemistry, Faculty of Science, Aswan University, Aswan, Egypt.
}

\begin{abstract}
Compound (2) was prepared from the reaction of ethyl-2-oxo-2H-coumarin-3-carboxylate (1) with ethylcyanoacetate in ethanol containing a catalytic amount of piperidine as catalyst. Compound (2) is the key intermediate for the synthesis of several series of new compounds such as ((pyrimidine, tetrazine, piperidine, oxazepine)-2H-coumarin-2-one derivatives by reaction with selected reagents such as urea, cyanoacetamide, cyanoacetohydrazide, orthoaminophenol and 5-aminotriazole.
\end{abstract}

Keywords: (pyrimidine, tetrazine, piperdine, oxazepine)-2H-coumarin-2-one derivatives.

\section{Introduction}

Coumarins, an old class of compounds, are a family of naturally occurring compounds [1,2]. These compounds are involved in the actions of plant growth hormones and growth regulators, the control of respiration, photosynthesis, as well as defense against infection [3]. Also, they have important effects in plant biochemistry and physiology, acting as antioxidants, enzyme inhibitors and precursors of toxic substances [3]. Coumarins and their derivatives are used in the field of biology, medicine and polymer science. They are also, present or used in perfumes and cosmetics [4, 8] cigarettes [5-8], alcoholic beverages [9] and laser dye [10]. In addition, coumarins have been found to be connected with a number of cases of homicide and suicide in Korea [11]. Coumarins were first synthesized via the Perkin reaction, and many simple coumarins are still prepared through this method, the Knoevemagel reaction emerged as an important synthetic method to synthesized coumarin derivatives with carboxyl group at the 3-position [12, 13]. Many other synthetic methods for coumarins have been reported, including the Pechmann [14], Reformatsky [15] and Witting reactions [16]. The review is not exhaustive, it is intended to acquaint the reader with interesting group of synthetic organic compounds.

\section{Materials \& Methods}

All melting points are measured using Galenkamp melting point apparatus and are uncorrected. Elemental analysis was carried out at the Microanalytical Center of Cairo University by an automatic analyzer (Heraeus).. IR (KBr pellets) spectra were determined in 1650 FT-9R instrument (Cairo University). ${ }^{1} \mathrm{H}$ NMR spectra were accomplished using $300 \mathrm{MHz}$ NMR Spectrometer and mass spectroscopy were recorded on GCMS-QP-1000 EX spectrometer (Cairo University).
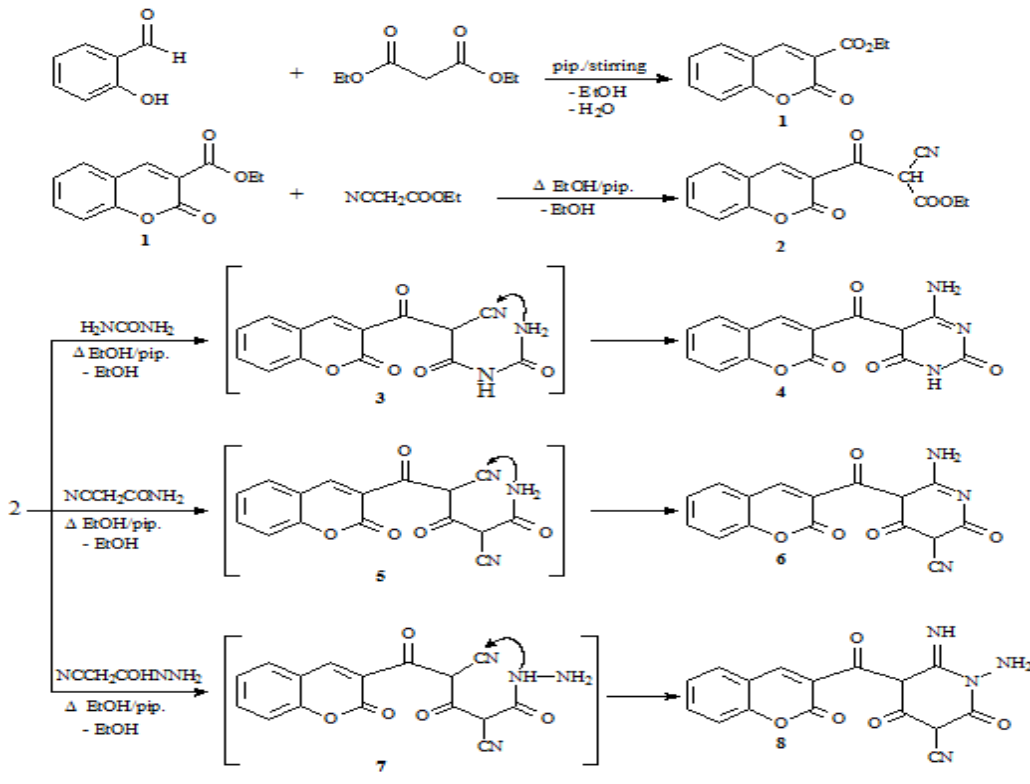


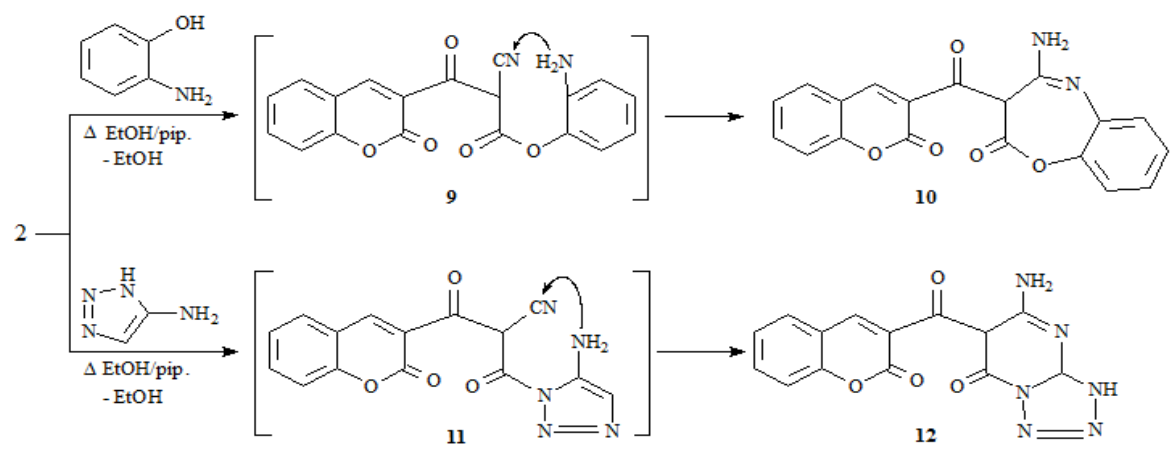

Scheme 2 Continue

Synthesis of 3-(2-cyano-1-ethoxy-1,3-oxo-prop-3-yl)-2H-coumarin-2H-2-one (2):

A mixture of $1(0.43 \mathrm{~g}, 2 \mathrm{mmol})$, ethylcyanoacetate $(0.23 \mathrm{ml}, 2 \mathrm{mmol})$ in $30 \mathrm{ml}$ ethanol containing piperidine $(0.1 \mathrm{ml})$ was refluxed for 5 hours. The reaction mixture was evaporated under reduced pressure, the residue was triturated with methanol and the resulting product was collected by filtration, washed with methanol and crystallized from methanol. The results are registered in Table $(1,2)$.

\section{Synthesis of 3-[keto-(2,3,4H-6-amino-2,4-dioxo-pyrimidine-5yl)]2H-coumarin-2one (4).}

A mixture of $2(0.57 \mathrm{~g}, 2 \mathrm{mmol})$ and urea $(0.12 \mathrm{~g}, 2 \mathrm{mmol})$ in ethanol $(30 \mathrm{ml})$ containing piperidine $(0.1 \mathrm{ml})$ was refluxed for 5 hours, the reaction mixture was evaporated under reduced pressure, the residue was triturated with cold water and the resulting product was collected by filtration, washed with cold water and crystallized from ethanol. The results are registered in Table $(1,2)$.

Synthesis of 3-[keto-(2,3,4H-6-amino-3-cyano-2,4-dioxo-azine-5-yl)]-2H-coumarin-2-one (6):

A mixture of $2(0.57 \mathrm{~g}, 2 \mathrm{mmol})$ and cyanoacetamide $(0.17 \mathrm{~g}, 2 \mathrm{mmol})$ in $30 \mathrm{ml}$ ethanol containing piperidine $(0.1 \mathrm{ml})$ was refluxed for 6 hours, the reaction mixture was evaporated under reduced pressure, the residue was triturated with methanol and the resulting product was collected by filtration, washed with methanol and crystallized from methanol. The results are registered in Table $(1,2)$.

\section{Synthesis of 3[keto-(2,3,4,6H-1-amino-3-cyano-2,4-dioxo-6-imino-piperidine-5-yl)]-2H-coumarin-2-one} (8):

A mixture of $2(0.57 \mathrm{~g}, 2 \mathrm{mmol})$ and cyanoacetohydrazide $(0.20 \mathrm{~g}, 2 \mathrm{mmol})$ in $30 \mathrm{ml}$ ethanol containing piperidine $(0.1 \mathrm{ml})$ was refluxed for 6 hours, the reaction mixture was evaporated under reduced pressure, the residue was triturated with ethanol and the resulting product was collected by filtration, washed with ethanol and crystallized from dioxane. The results are registered in Table $(1,2)$.

Synthesis of 3-[keto-(7H-5-amino-7-oxo-benzo[b]oxazepine-6-yl)]-2H-coumarin-2-one (10):

A mixture of $2(0.57 \mathrm{~g}, 2 \mathrm{mmol})$ and orthoaminophenol $(0.22 \mathrm{~g}, 2 \mathrm{mmol})$ in $30 \mathrm{ml}$ ethanol containing piperidine $(0.1 \mathrm{ml})$ was refluxed for 5 hours, the reaction mixture was evaporated under reduced pressure, the residue was triturated with methanol and the resulting product was collected by filtration, washed with methanol and crystallized from ethanol. The results are registered in Table $(1,2)$.

Synthesis of 3-[keto-(6H-4-amino-2-oxo-1,3,4,5-tetrazolo[1,2a] pyrimidine-5-yl)]-2H-coumarin-2-one (12):

A mixture of $2(0.57 \mathrm{~g}, 2 \mathrm{mmol})$ and 5 -aminotriazole $(0.17 \mathrm{~g}, 2 \mathrm{mmol})$ in $30 \mathrm{ml}$ ethanol containing piperidine $(0.1 \mathrm{ml})$ was refluxed for 6 hours, the reaction mixture was evaporated under reduced pressure, the residue was triturated with cold water and the resulting product was collected by filtration, washed with cold water and crystallized from water. The results are registered in Table $(1,2)$.

Table 1: Characterization of the prepared compounds

\begin{tabular}{|c|c|c|c|c|c|c|c|c|c|c|}
\hline \multirow[t]{3}{*}{ Comp. No } & \multicolumn{3}{|c|}{ Nature of products } & \multirow{3}{*}{$\begin{array}{l}\text { Molecular } \\
\text { formula (M.Wt) }\end{array}$} & \multicolumn{6}{|c|}{ Analysis \% } \\
\hline & \multirow{2}{*}{ Colour } & \multirow{2}{*}{$\begin{array}{l}\text { Yield } \\
\%\end{array}$} & \multirow{2}{*}{$\begin{array}{l}\text { M.p. } \\
{ }^{\circ} \mathrm{C}\end{array}$} & & \multicolumn{3}{|c|}{ Calculated } & \multicolumn{3}{|c|}{ Found } \\
\hline & & & & & $\mathrm{C}$ & $\mathrm{H}$ & $\mathrm{N}$ & $\mathrm{C}$ & $\mathrm{H}$ & $\mathrm{N}$ \\
\hline 2 & White & 62 & $\begin{array}{l}100- \\
103\end{array}$ & $\begin{array}{l}\mathrm{C}_{15} \mathrm{H}_{11} \mathrm{NO}_{5} \\
(285.253)\end{array}$ & 63.16 & 3.89 & 4.91 & 63.33 & 3.89 & 4.99 \\
\hline 4 & White & 66.6 & $95-97$ & $\begin{array}{l}\mathrm{C}_{14} \mathrm{H}_{9} \mathrm{~N}_{3} \mathrm{O}_{5} \\
(299.24)\end{array}$ & 56.19 & 3.03 & 14.02 & 56.28 & 3.09 & 14.10 \\
\hline 6 & Yellow & 63 & $\begin{array}{l}180- \\
183\end{array}$ & $\begin{array}{l}\mathrm{C}_{16} \mathrm{H}_{9} \mathrm{~N}_{3} \mathrm{O}_{5} \\
(324.85)\end{array}$ & 59.46 & 2.79 & 12.93 & 59.53 & 2.85 & 12.97 \\
\hline
\end{tabular}


Simple Synthesis Of Some Novel Polyfunctionally Derivatives Of 2H-Coumarin-2-One.

\begin{tabular}{|l|l|l|l|l|l|l|l|l|l|l|l|}
\hline $\mathbf{8}$ & Orange & 75 & $\begin{array}{l}210 \\
211\end{array}$ & $\begin{array}{l}\mathrm{C}_{16} \mathrm{H}_{10} \mathrm{~N}_{4} \mathrm{O}_{5} \\
(338.28)\end{array}$ & 56.81 & 2.98 & 16.56 & 56.86 & 2.99 & 16.63 \\
\hline $\mathbf{1 0}$ & Red & 63 & 237 & - & $\begin{array}{l}\mathrm{C}_{19} \mathrm{H}_{12} \mathrm{~N}_{2} \mathrm{O}_{5} \\
(348.31)\end{array}$ & 65.52 & 3.47 & 8.04 & 65.55 & 3.52 & 8.08 \\
\hline $\mathbf{1 2}$ & White & 76 & $\begin{array}{l}239 \\
100\end{array}$ & $-\begin{array}{l}\mathrm{C}_{15} \mathrm{H}_{9} \mathrm{~N}_{5} \mathrm{O}_{4} \\
(323.27)\end{array}$ & 55.73 & 2.81 & 21.66 & 55.80 & 2.90 & 21.75 \\
\hline
\end{tabular}

Table 2: IR and ${ }^{1} \mathrm{H}$ NMR (Mass) Spectral Data of the Prepared Compounds.

\begin{tabular}{|c|c|c|}
\hline Comp. No & IR Spectrum $\left(\mathrm{KBr}, \mathrm{Cm}^{-1}\right)$ & ${ }^{1}$ H NMR Spectrum (DMSO, $\left.\delta\right) ; \&$ (Mass data) \\
\hline 2 & 1205 (CO) ester, $1707(\mathrm{CO}), 2220(\mathrm{CN})$. & $\begin{array}{l}1.3\left(\mathrm{t}, 3 \mathrm{H}, \mathrm{CH}_{3}\right), 4.12\left(\mathrm{q}, 2 \mathrm{H}, \mathrm{CH}_{2}\right), 4.19(\mathrm{~s}, 1 \mathrm{H}, \mathrm{CH}), 7.02-7.27(\mathrm{~m}, \\
4 \mathrm{H}, \mathrm{Ar}-\mathrm{H}), 8.65(\mathrm{~s}, 1 \mathrm{H}, \mathrm{CH} \text {, heterocyclic nuclei). } \\
\left(\mathrm{M}^{-1}\right): 284 .\end{array}$ \\
\hline 4 & $1689-1720(\mathrm{C}=\mathrm{O}), 3400-3100\left(\mathrm{NH}_{2}-\mathrm{NH}\right)$ & $\begin{array}{l}2.0\left(\mathrm{~s}, 2 \mathrm{H}, \mathrm{NH}_{2}\right), 3.3(\mathrm{~s}, 1 \mathrm{H}, \mathrm{CH}), 7.02-8.85(\mathrm{~m}, 5 \mathrm{H}, \mathrm{Ar}-\mathrm{H}), 10.02(\mathrm{~s}, \\
1 \mathrm{H}, \mathrm{NH}) .\left(\mathrm{M}^{+}\right): 229 .\end{array}$ \\
\hline 6 & 1689-1707 (C=O), $2218(\mathrm{CN}), 3360\left(\mathrm{NH}_{2}\right)$ & $\begin{array}{l}2.03\left(\mathrm{~s}, 2 \mathrm{H}, \mathrm{NH}_{2}\right), \delta 3.2(\mathrm{~s}, 1 \mathrm{H}, \mathrm{CH}), \delta 4.22(\mathrm{~s}, 1 \mathrm{H}, \mathrm{CH}), \delta 7.02-8.65 \\
(\mathrm{~m}, 5 \mathrm{H}, \mathrm{Ar}-\mathrm{H}) . \\
\left(\mathrm{M}^{+}\right): 323 .\end{array}$ \\
\hline 8 & $\begin{array}{l}\text { 1689-1715 (C=O), } 2218(\mathrm{CN}), 3282(\mathrm{NH}), \\
3401\left(\mathrm{NH}_{2}\right) .\end{array}$ & $\begin{array}{l}2.0\left(\mathrm{~s}, 2 \mathrm{H}, \mathrm{NH}_{2}\right), 3.20(\mathrm{~s}, 1 \mathrm{H}, \mathrm{CH}), 4.3(\mathrm{~s}, 1 \mathrm{H}, \mathrm{CH}), 5.11(\mathrm{~s}, 1 \mathrm{H}, \mathrm{NH}), \\
7.02-8.65(\mathrm{~m}, 5 \mathrm{H}, \mathrm{Ar}-\mathrm{H}) . \\
\left(\mathrm{M}^{-1}\right): 337 .\end{array}$ \\
\hline 10 & $1690-1710(\mathrm{C}=\mathrm{O}), 3360\left(\mathrm{NH}_{2}\right)$. & $\begin{array}{l}2\left(\mathrm{~s}, 2 \mathrm{H}, \mathrm{NH}_{2}\right), 3.2(\mathrm{~s}, 1 \mathrm{H}, \mathrm{CH}), 7.02-8.65(\mathrm{~m}, 9 \mathrm{H}, \mathrm{Ar}-\mathrm{H}) . \\
\left(\mathrm{M}^{+}\right): 348 .\end{array}$ \\
\hline 12 & $1689-1707(\mathrm{C}=\mathrm{O}), 3432\left(\mathrm{NH}_{2}\right)$. & $\begin{array}{l}1.5\left(\mathrm{~s}, 2 \mathrm{H}, \mathrm{NH}_{2}\right), 2.0\left(\mathrm{~s}, 2 \mathrm{H}, \mathrm{NH}_{2}\right), 3.3(\mathrm{~s}, 1 \mathrm{H}, \mathrm{CH}), 3.6(\mathrm{~s}, 1 \mathrm{H}, \mathrm{CH}) \\
7.02-8.85(\mathrm{~m}, 5 \mathrm{H}, \mathrm{Ar}-\mathrm{H}) . \\
\left(\mathrm{M}^{-1}\right): 332 .\end{array}$ \\
\hline
\end{tabular}

\section{Results \& Disscusion}

The ethyl-2-oxo-2H-coumarin-3-carboxylate (1) was originally prepared by reaction between salicylalddhyde and diethyl malonate in presence of piperidine, a procedure later simplified by [17], elimination of ethanol molecule via reaction of compound (1) with ethyl cyanoacetate in presence of piperidine as catalyst afford 3-(2-cyano-1-ethoxy-1,3-oxo-prop-3-yl)-2H-coumarin-2-one (2). The synthetic strategies adopted for the synthesis of the intermediates and target compounds are depicted in the Scheme 2.

Compound (2) was considered good starting material for preparing many (pyrimidine, pyridine, piperidine, oxazepine)-2H-coumarin-2-one derivatives thus, the reaction of (2) with different amines via elimination of ethanol molecule afforded intermediates $(3,5,7,9,11)$ which cyclized by nucleophilic addition of amine into the cyano group to afford derivatives $(4,6,8,10,12)$, all these products were confirmed by analytical and spectral analysis (Table 1,2).

\section{Conclusion}

The method which was used for preparation procedure was an efficient,simple for preparation of multisupstituted (pyrmidine, tetrazine, piperidine, oxazepine)-2H-coumarin derivatives by the reaction of 3- (2cyano-1-ethoxy-1,3-oxo-prop-3-yl)-2H-coumarin-2-one with selected amino reagents.

\section{Referencses}

[1]. $\quad$ Nicolaou, K.C.; Pfefferkorn, J.A.; Roecker, A.J.; Cao, G.Q.; Barluenga, S.; Mitchell, H.J.; J. Am., 2000, Chem. Soc., 122, 9939 9953.

[2]. Kazoo, M.; Kazuya, O.; Hironobu, H. Mukai, K.; Okabe, K.; Hosose, J., 1989, Org. Chem., 54, 557-560

[3]. Kostova, I., 2005, Curr. Med. Chem., 5, 29-46.

[4]. Yourick, J.J.; Bronaugh, J., 1997, Appl. Toxicol. 17, 153-158.

[5]. O'Kennedy, R., 1997, John Wiley \& Sons, New York.

[6]. Nielson, B.E., 1971, Heywood in the Biology and Chemistry of the Umbelliferae, Academic Press, London.

[7]. Murray, R.D.H.; Mendez, J.; Brown, S.A., 1982, Chemistry and Biochemistry, John Wiely \& Sons, New York.

[8]. Yamazaki, H.; Tanaka, M.; Shimada, T. J. , 1999, Chromatogr. B., 721, 13-19.

[9]. Izquierdo, M.E.F.; Granados, J.Q.; Mir, V.M.; Martinez, M.G.L., 2000, Food Chem., 70, 251-258.

[10]. Ternor, S.R.; Shiltz, A.R.; Love, B.J.; Long, T.E., 2004, Chem. Rev., 104, 3059-3078.

[11]. Park, S.W.; Seo, B.S.; Kim, E.H.; Kim, D.H.; Paeng, K.J., 1996, Forensis Sci., 41, 685-688.

[12]. Knoevenagel, E., 1904, Chem. Ber., 37, 4461-4463.

[13]. Song, A.M.; Wang, X.B.; Lam, K.S., 2003, Lett., 41, 1775-1777.

[14]. Pechmann, H., 1884, Duisberg, Chem. Ber., 17, 929-936.

[15]. Shriner, R.L., 1942, Reformatsky reaction. Org. React., 1, 1-37.

[16]. Narasimahan, N.S.; Mali, R.S.; Barve, M.V., 1979, Synthetic Application of Lithiation Reactions, Part XIII. Synthesis of 3-phenyl coumarins and their benzo derivatives. Synthesis, 906-909.

[17]. Suresh, K.; Veeresh, M.; Prashant, A.; Mahesh, P.; Pardeepkumar, R. Shivalingarao, M., 2008, AHM Thippeswamy, Eur J Med Chem, 30, 1-7. 